Technical note

\title{
Effects of re-infection with Neospora caninum in bulls on parasite detection in semen and blood and immunological responses
}

\author{
I. Ferre ${ }^{\mathrm{a}, *}$, E. Serrano-Martínez ${ }^{\mathrm{a}}$, A. Martínez ${ }^{\mathrm{b}}$, K. Osoro $^{\mathrm{b}}$, A. Mateos-Sanz $^{\mathrm{a}}$, \\ I. del-Pozo ${ }^{c}$, G. Aduriz ${ }^{\text {c }}$, C. Tamargo ${ }^{\text {d }}$, C.O. Hidalgo ${ }^{\text {d }}$, L.M. Ortega-Mora ${ }^{\text {a }}$ \\ ${ }^{a}$ SALUVET, Departamento de Sanidad Animal, Facultad de Veterinaria, Universidad Complutense de Madrid (UCM), \\ Ciudad Universitaria s/n, E-28040 Madrid, Spain \\ b Área de Sistemas de Producción Animal, Servicio Regional de Investigación y Desarrollo Agroalimentario (SERIDA), \\ Consejería de Medio Rural y Pesca, Asturias, E-33300 Villaviciosa, Spain \\ ${ }^{\mathrm{c}}$ Departamento de Sanidad Animal, Instituto Vasco de Investigación y Desarrollo Agrario (NEIKER), \\ Berreaga 1, E-48160 Derio, Bizkaia, Spain \\ d Área de Selección y Reproducción Animal, Servicio Regional de Investigación y Desarrollo Agroalimentario (SERIDA), \\ Consejería de Medio Rural y Pesca, Asturias, E-33202 Gijón, Spain
}

Received 12 July 2007; received in revised form 26 September 2007; accepted 9 November 2007

\begin{abstract}
Three bulls with experimentally induced primary infection with Neospora caninum were re-infected intravenously with $10^{8}$ live $N$. caninum tachyzoites of the NC-1 isolate at 300 days post-infection to investigate the presence of $N$. caninum in semen and blood, and the associated immune responses. In parallel, three bulls with experimentally induced primary infection with $N$. caninum and three noninfected bulls were also monitored. Re-infected and infected bulls showed an intermittent presence of $N$. caninum DNA in semen with a parasite load ranging from 0.1 to 15.6 (mean 4.4) and 0.1 to 11.1 (mean 4.1) parasites/ml, respectively. Re-infected bulls showed significant and persistent serum-specific IgM and IgG antibody responses. Specific IgG levels were detected in seminal plasma of all infected bulls, but the magnitude of the response was significantly higher in re-infected rather than in chronically infected animals. The mean specific IFN- $\gamma$ levels in re-infected bulls were significantly increased as early as 3 and 7 days after experimental infection when compared to bulls in other groups. This study showed that the intermittent presence and parasite load of $N$. caninum in the semen of reinfected bulls is very similar to that reported in chronically infected animals. The protozoa could not be isolated from BALB/c $n u / n u$ mice inoculated with PCR-positive semen samples and inseminated heifers with pooled semen samples did not show seroconversion. Plasma IFN- $\gamma$ level seems to be a good indicator of a recent $N$. caninum infection.
\end{abstract}

(C) 2008 Elsevier Inc. All rights reserved.

Keywords: Neospora caninum; Bull; Semen; Immune response; Bioassay

\section{Introduction}

Since, Neospora caninum DNA was reported in fresh and frozen semen from naturally infected bulls [1],

\footnotetext{
* Corresponding author. Tel.: +34 91 3944094; fax: +34 913943908 .

E-mail address: iferrepe@vet.ucm.es (I. Ferre).
}

several studies have been carried out to investigate the possibility of venereal transmission in bovine neosporosis. The presence of $N$. caninum DNA in fresh semen of naturally [2] and experimentally [3] infected bulls was intermittent and the parasite load was low $(0.1$ and 14.5 parasites $/ \mathrm{ml}$ of semen). A recent experimental study showed that the intrauterine infection via contaminated semen using $5 \times 10^{4}$ tachyzoites caused persistent serum-specific antibody responses in some 
heifers [4]. In persistently infected cattle, the reactivation (recrudescence) of the infection (caused by stress or immunosuppressive diseases) or ingestion of sporulated $N$. caninum oocysts could result in parasitaemia, leading to the dissemination of $N$. caninum throughout the body, including the genital tract [5]. In bulls, this fact could increase the number of parasites in semen and thus, lead to venereal infection risk. The present work is a follow-up study in bulls with experimentally induced primary infection with $N$. caninum which were re-infected with $N$. caninum tachyzoites to evaluate the effect of re-infection on parasite load shedding in semen.

\section{Materials and methods}

\subsection{Bulls and experimental design}

Nine bulls of the Asturiana de los Valles breed, ranging in age from 3.9 to 12.6 (mean 5.8) years old, weighing from 806 to 1158 (mean 954) kg, and trained for semen collection were selected for this study. Six of the bulls were infected 10 months before with $10^{8}$ tachyzoites of $N$. caninum [3] and the other three were non-infected. Bulls were allocated into three groups (AC) composed of three animals each. Groups A and B included bulls with experimentally induced primary infection with $N$. caninum and only bulls in group A were experimentally re-infected intravenously with $10^{8}$ live $N$. caninum tachyzoites of NC-1 isolate. Group C included non-infected control bulls. Tachyzoites used for experimental infections and infection procedure were described previously [3]. The presence of $N$. caninum DNA in semen and blood, serological (IgG, IgG1, IgG2, and IgM) and IFN- $\gamma$ responses, and specific IgG and IgA levels in seminal plasma of bulls was assessed. Bulls were monitored for 13 weeks. Individual and pooled semen samples of bulls from groups A and B were bioassayed in a BALB/c nu/nu mouse model and in synchronized seronegative heifers by means of AI, respectively.

\subsection{Sample collection and preparation}

Sample collection and preparation was previously explained [3]. For the bioassay in heifers, a weekly pooled semen sample was prepared with excess semen collected from each bull from groups A and B. The pooled semen sample (total volume oscillated between 6 and $15 \mathrm{ml}$ ) was stored in a sterile container at $37^{\circ} \mathrm{C}$ in a water bath until used. Sample preparation, inoculation of mice, and insemination of synchronized heifers were performed immediately after semen collection from bulls from groups A and B.

\subsection{PCR procedures}

DNA from whole blood, seminal fluid and the nonsperm cell fraction were analysed separately using nested-PCR as described [1]. N. caninum DNA from nested-PCR positive semen samples was quantified by a real-time PCR test [6].

\subsection{Bioassay in BALB/c nu/nu mice and heifers}

The bioassay procedure was previously described [2,3]. In parallel, experimental infections were done with bovine semen artificially contaminated with different quantities of $N$. caninum tachyzoites of the NC-1 strain using BALB/c nu/nu mice to assess the capability of the parasite to induce an infection within this animal model in order to assess the sensitivity of this bioassay methodology. Five groups of 6-week-old female athymic mice were used. They were intraperitoneally infected with $10,10^{2}, 10^{3}, 10^{4}$, and $10^{5}$ tachyzoites resuspended in $400 \mu \mathrm{l}$ of semen from a $N$. caninum seronegative bull. Positive $\left(10^{3}\right.$ tachyzoites diluted in PBS) and negative (only semen) control groups were also included. Afterwards, inoculated mice were examined daily and killed with $\mathrm{CO}_{2}$ gas at 20 weeks post-inoculation. At necropsy, brain was removed aseptically and examined by a nestedPCR procedure [7].

Eleven cyclic heifers of the Asturiana de los Valles breed, ranging in age from 15 to 28 (mean 19) months and weighing from 337 to 420 (mean 380) kg were used for the bioassay. Before starting, blood samples were taken from all 11 heifers and tested for evidence of exposure to $N$. caninum, bovine viral diarrhoea virus (BVDV), infectious bovine rhinotracheitis virus (IBRV), Leptospira hardjo and Brucella abortus (assays conducted by the Instituto Vasco de Investigación y Desarrollo Agrario, NEIKER, Derio, Spain). The heifers were negative for all five abortifacient agents. The 11 heifers were artificially inseminated using standard techniques with weekly pooled semen samples. One heifer was artificially inseminated each week between 21 and 91 days after the experiment began. Before AI, all cyclic heifers were synchronized hormonally with two doses of a synthetic PGF2 $\alpha$ analogue given 11 days apart $(2 \mathrm{ml}$ i.m., Prosolvin, Intervet, Salamanca, Spain). Oestrus detection (day $0 ; 2.5$ days after the second PGF2 $\alpha$ analogue administration on average) was based on monitoring behavioural signs three times daily as serum progesterone levels. The heifers were monitored daily for 100 days post-insemination and pregnancy was diagnosed by transrectal ultrasonography on days 34 and 60 after insemination. Blood samples were collected fortnightly 
Table 1

$N$. caninum DNA detection by nested-PCR in semen and blood samples of three bulls (group A) with experimentally induced primary infection with $N$. caninum which were re-infected with $10^{8} \mathrm{~N}$. caninum tachyzoites of the $\mathrm{NC}-1$ isolate and three bulls (group B) with experimentally induced primary infection with $N$. caninum

\begin{tabular}{|c|c|c|c|c|c|c|c|c|c|c|c|c|c|c|c|c|}
\hline \multirow[t]{2}{*}{ Group } & \multirow[t]{2}{*}{ Bull } & \multicolumn{15}{|c|}{ Days after re-infection (group A)/days after experiment started (group B) } \\
\hline & & 0 & 7 & 10 & 14 & 21 & 29 & 36 & 43 & 50 & 57 & 64 & 71 & 78 & 85 & 91 \\
\hline \multirow[t]{3}{*}{ A (re-infected) } & 4852 & $\mathrm{~S}(7.8)$ & $\mathrm{P}$ & $\mathrm{P}$ & $\mathrm{P}$ & - & - & S (1.8) & - & $\mathrm{S}(0.1)$ & - & - & - & - & - & - \\
\hline & 90 & S (5.8) & P, S (2.0) & $\mathrm{P}$ & - & $\mathrm{P}$ & $\mathrm{P}$ & $\mathrm{P}$ & S (4.4) & - & - & S (4.2) & - & S (2.7) & S (4.0) & - \\
\hline & 4375 & - & P, S (15.6) & $\mathrm{P}$ & $\mathrm{P}, \mathrm{S}(0.1)$ & - & - & - & - & - & - & - & - & - & - & - \\
\hline \multirow{3}{*}{$\begin{array}{l}\text { B (not } \\
\text { re-infected) }\end{array}$} & 6507 & - & S (9.6) & - & - & - & $\mathrm{P}, \mathrm{S}(2.5)$ & S (1.4) & S (1.6) & - & - & S (3.4) & $S(0.1)$ & S (2.3) & - & - \\
\hline & 1940 & $\mathrm{~S}(2.5)$ & - & - & - & - & $\mathrm{S}(0.1)$ & - & - & - & - & $S(0.1)$ & - & S (5.0) & - & - \\
\hline & 6367 & - & S (11.1) & - & - & - & S (11.1) & - & - & - & - & - & S (7.2) & - & - & - \\
\hline
\end{tabular}

Animals were monitored for 91 days.

Parasite load (number of parasites/ml of semen) determined by real-time PCR in nested-PCR positive semen samples is indicated within parentheses. $\mathrm{S}$, detected in semen; $\mathrm{P}$, detected in blood; -, not detected.

by coccygeal venipuncture in plain tubes for serological analysis. Serum samples were assayed for specific IgG antibodies using a commercial kit (CIVTEST ${ }^{\mathrm{TM}}$ ). Positive and negative controls of the bioassay in heifers were also carried out and published [4].

\subsection{Assessment of $N$. caninum-specific immune responses}

Serum and undiluted seminal plasma samples were assayed for specific IgM, IgG, IgG1 and IgG2, and IgG and IgA antibodies, respectively using a commercial kit $\left(\right.$ CIVTEST $^{\mathrm{TM}}$ ) as previously described [3]. To assess IFN- $\gamma$ production, duplicate plasma samples were tested using a commercial ELISA kit (Bovigam IFN$\gamma$ kit, CSL, Australia) as previously described [3].

\subsection{Statistical analysis}

Independent two-sample $t$-tests were performed to compare the antibody and IFN- $\gamma$ responses between bulls from groups $\mathrm{A}-\mathrm{C}$. The association between the detection of $N$. caninum DNA in semen and/or blood and serological and IFN- $\gamma$ specific responses in bulls from groups A and B were analysed by the Wilkonson Rank-test. Statistical analyses were performed using SAS Software v.8.2. (SAS Institute Inc.). All statistical analyses were considered significant when $P<0.05$.

\section{Results}

\subsection{Detection of N. caninum DNA and bioassays in $B A L B / c$ nu/nu mice and heifers}

The three bulls from group A showed parasitaemia between 7 and 36 days post-infection (pi), but only one bull (6507) from group B showed N. caninum DNA in blood at 29 days after the start of the experiment (Table 1). The presence of $N$. caninum DNA in semen was intermittent and the number of positive semen samples was similar in bulls from groups A and B (11 versus 14 , respectively). In all positive semen samples, specific-DNA was found in the cellular fraction and not in seminal plasma. The parasite load varied from 0.1 to 15.6 (mean $4.41 \pm 4.38$ ) and 0.1 to 11.1 (mean $4.14 \pm 4.01$ ) parasites per $\mathrm{ml}$ of semen in groups $\mathrm{A}$ and $\mathrm{B}$, respectively (Table 1). Mean individual parasite load varied from $3.23( \pm 4.05)$ to $7.85( \pm 10.96)$ in group $\mathrm{A}$ and $1.93( \pm 2.34)$ to $9.80( \pm 2.25)$ in group B.

A total of 90 athymic mice were inoculated with semen samples. Twenty-five mice were inoculated with PCR-positive semen samples containing an approximate tachyzoite number between 0.04 and 6.24 parasites per dose. No N. caninum DNA was detected by nested-PCR in the brain, lung or liver of BALB/c $n u$ / $n u$ mice inoculated. Experimental infections in athymic mice showed that Neospora DNA was found in the brains of mice inoculated with semen contaminated with at least $10^{3}$ tachyzoites and clinical signs associated with neosporosis (anorexia, inactivity, rounded back, and pelvic limb weakness) were detected in some mice inoculated with semen contaminated with $10^{4}$ and $10^{5}$ tachyzoites (Table 2). Eight of the 11 heifers were inseminated with a pooled semen sample containing some PCR-positive individual semen samples. The approximate number of tachyzoites included in pooled semen samples oscillated between 0.2 and 27.4. No N. caninum-specific antibody responses were detected in any of the heifers inseminated. All but two heifers became pregnant and gave birth to calves that did not show precolostral specific antibodies to $N$. caninum. 
Table 2

Presence of Neospora DNA in brains of BALB/c $n u / n u$ mice inoculated intraperitoneally with bovine semen contaminated with different N. caninum (NC-1 isolate) quantities

\begin{tabular}{ll}
\hline $\begin{array}{l}\text { Number of } \\
\text { tachyzoites in semen }\end{array}$ & $\begin{array}{l}\text { Neospora DNA in brain } \\
\text { (positives/total tested) }\end{array}$ \\
\hline 10 & $0 / 4$ \\
$10^{2}$ & $0 / 4$ \\
$10^{3}$ & $3 / 7$ \\
$10^{4}$ & $3 / 3^{*}$ \\
$10^{5}$ & $3 / 3^{* *}$ \\
$10^{3}$ (PBS) & $2 / 2^{* * *}$ \\
0 (semen) & $0 / 3$
\end{tabular}

${ }^{*}$ Two mice showed clinical signs and were sacrificed at 23 days post-inoculation.

${ }_{* * *}$ Three mice showed clinical signs and one animal at 23 days and two animals at 28 days post-inoculation were sacrificed.

*** One mouse showed clinical signs and was sacrificed at 22 days post-inoculation.

\subsection{N. caninum-specific immune responses}

Bulls from group A showed significant $(P<0.05)$ increased mean specific IgM antibody levels to $N$. caninum between 7 and 91 days pi (Fig. 1a) when compared with bulls from groups $\mathrm{B}$ and $\mathrm{C}$, respectively. In re-infected bulls, mean anti- $N$. caninum IgG levels increased from 7 days pi and were significantly higher $(P<0.05)$ than in groups $\mathrm{B}$ and $\mathrm{C}$ during the entire experimental period (Fig. 1b). Specific serum IgG antibody levels in bulls from group B were higher than in controls, but in bulls 1940 and 6507, the value fell below the cut-off value between 43 and 92, and 85 and 92 days after the experiment started, respectively. Mean IgG1 levels remained significantly $(P<0.05)$ elevated in all bulls from group A compared to groups B and C, but decreased progressively (Fig. 1c). The mean levels of IgG2 in re-infected bulls increased from 7 days pi and were significantly $(P<0.05)$ higher compared to groups $\mathrm{B}$ and $\mathrm{C}$ (Fig. 1d). No significant association was found between the presence and quantity of $N$. caninum DNA in semen and the magnitude of specific IgG, IgG1, IgG2 or IgM responses in bulls from groups $\mathrm{A}$ and $\mathrm{B}$, respectively. In seminal plasma, mean anti- $N$. caninum IgG levels in re-infected bulls were significantly higher $(P<0.05)$ than in groups $\mathrm{B}$ and $\mathrm{C}$ from 21 to 91 days pi (Fig. 1e). No differences were detected in seminal plasma IgA antibody levels between groups A and $\mathrm{B}$ and control bulls (data not shown). The mean specific IFN- $\gamma$ levels in re-infected bulls were higher than in groups B and C as soon as 3 (bulls 90 and 4375) and 7 (bull 4852) days pi (Fig. 1f), but decreased soon thereafter. No significant associations were observed between the presence and magnitude of $N$. caninum DNA in semen and IFN- $\gamma$ production levels, nor among IgG2 antibody levels, IgG1/IgG2 ratio, and IFN- $\gamma$ levels in bulls from groups $\mathrm{A}$ and $\mathrm{B}$, respectively.

\section{Discussion}

This study demonstrated that the intermittent presence and the low number of parasites in semen observed in re-infected bulls were very similar to that reported in animals after primary infection [3]. When these results were compared with those reported in naturally infected bulls (probably infected prenatally by the endogenous transplacental route) [2], two significant differences were observed. First, all experimentally infected bulls showed $N$. caninum DNA in semen at some time during the course of the study (100\% versus $62.5 \%$, respectively). Second, the mean parasite load was approximately twice the quantity reported in naturally infected bulls (6 tachyzoites $/ \mathrm{ml}$ versus 3 tachyzoites $/ \mathrm{ml}$ of semen, respectively). However, the maximum parasite load found in semen samples of re-infected bulls ( 15.6 tachyzoites $/ \mathrm{ml}$ ) suggests an ejaculate containing bearly 200 tachyzoites. Two recent studies support our findings. Staubli et al. [8] found no positive semen samples when investigating five separate semen specimens from 20 seropositive bulls used for AI in Switzerland. In Brasil, only one of 55 seropositive bulls from AI centers showed $N$. caninum DNA in semen samples [9].

Unfortunately, we cannot conclude that live infectious $N$. caninum stages were present in semen because of the inability to isolate the protozoa from positive PCR semen samples. Lack of success in isolating $N$. caninum from semen could be explained by two causes. First, the toxic effects of bovine semen in athymic $\mathrm{BALB} / \mathrm{c} n u / n u$ mouse did not allow us to inoculate more than $400 \mu \mathrm{l}$ of fresh semen in each animal and second, there was a low parasite load found in semen in relation to the detection threshold in the murine and bovine models. Parasite viability may not be compromised because positive semen samples were inoculated immediately after semen extraction. The total number of parasites in $400 \mu \mathrm{l}$ of fresh bovine semen was less than 6 tachyzoites and the experimental infections in athymic mice with artificially contaminated semen indicate that at least $10^{3}$ tachyzoites are necessary in bovine semen to induce an infection in an athymic $\mathrm{BALB} / \mathrm{c} n u / n u$ mouse. An interesting issue of the present work was the insemination of seronegative cyclic heifers with pooled semen from infected bulls in order to evaluate the viability of parasites shed in 
(a)

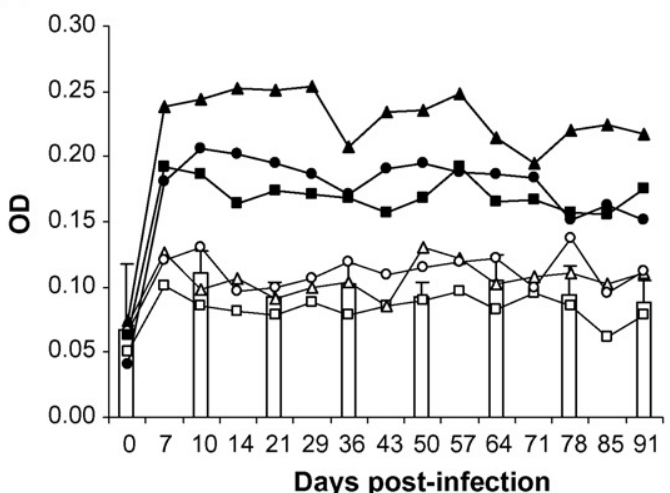

(c)

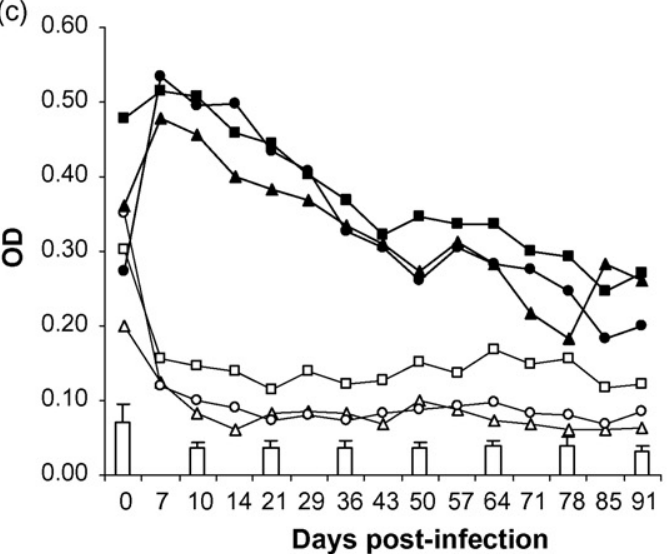

(e)

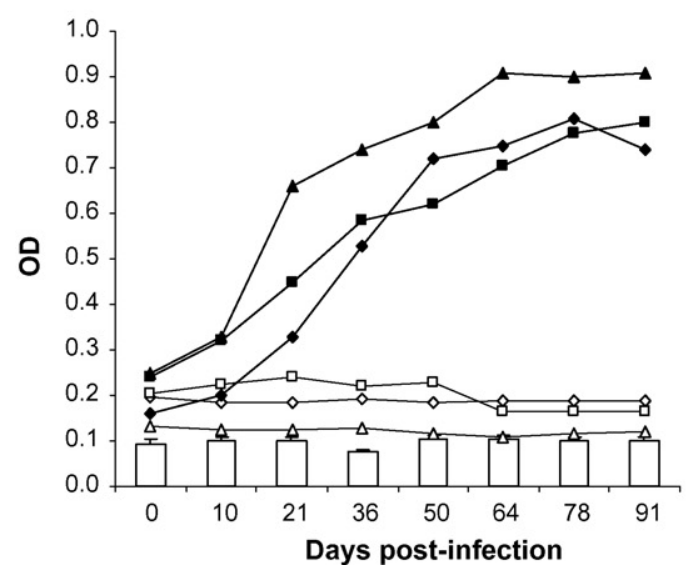

(b)

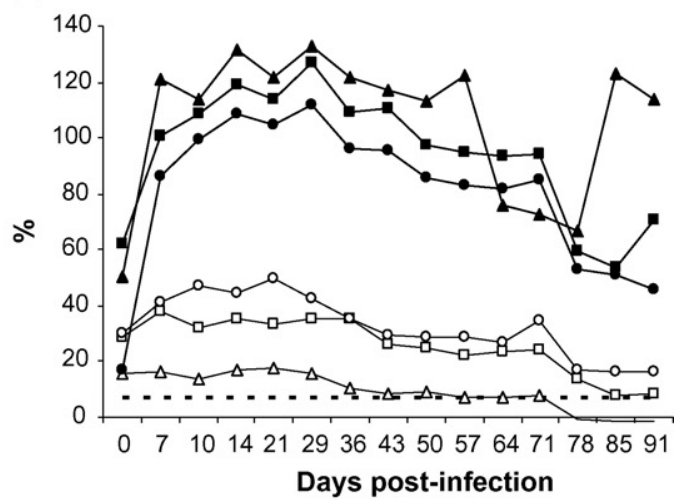

(d)

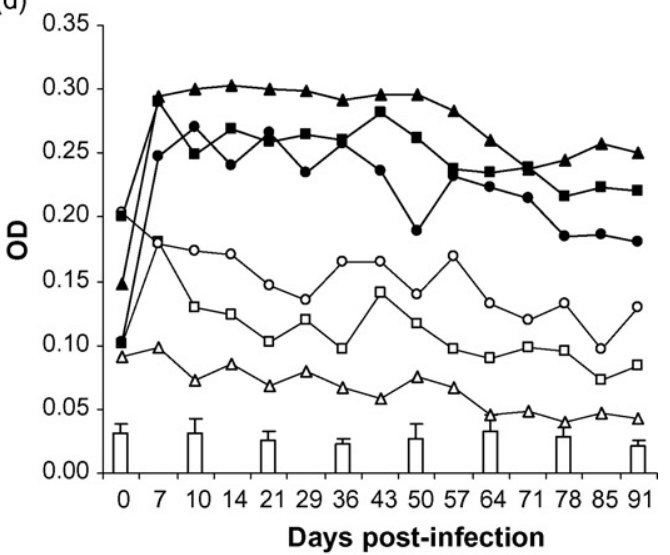

(f)

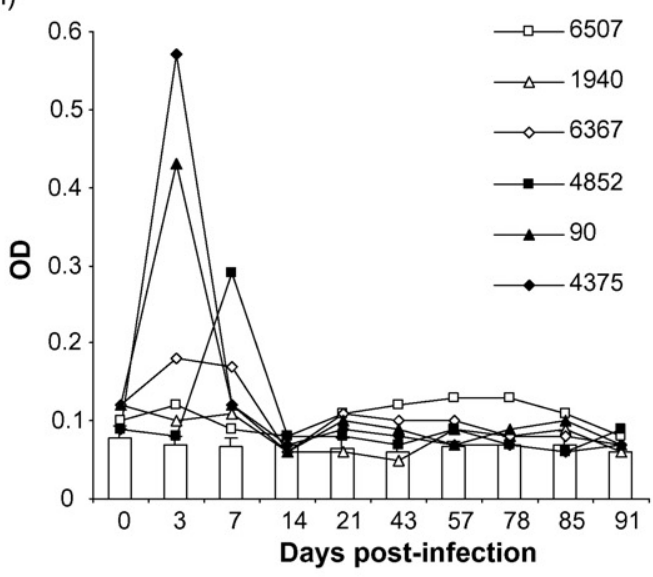

Fig. 1. Specific antibody and IFN- $\gamma$ responses to $N$. caninum in monitored bulls: (a) serum IgM; (b) serum IgG; (c) serum IgG1; (d) serum IgG2; (e) seminal plasma IgG; (f) IFN- $\gamma$. For IgM, IgG subclasses, seminal plasma IgG, and IFN- $\gamma$, the graphs show the individual OD of three bulls with experimentally induced primary infection with $N$. caninum which were re-infected with $10^{8} \mathrm{~N}$. caninum tachyzoites of the NC-1 isolate (solid dotted black line), three bulls with experimentally induced primary infection with $N$. caninum (broken dotted white line) and the mean OD \pm S.D. of three control non-infected (vertical white bars) bulls, respectively. The serum IgG results are expressed as relative index $\times 100$ values and the cut-off value is indicated as a broken line. 
semen. However, the low number of parasites shed in semen was probably inadequate to produce an infection in heifers. The maximum number of parasites included in a pooled semen sample only reached 27 tachyzoites. In a recent study, we have demonstrated a threshold level of between 5000 and 50,000 tachyzoites for horizontal transmission via contaminated semen [4], which seems to be very different from the parasite load described in semen of experimentally and naturallyinfected bulls.

Inoculation with $N$. caninum tachyzoites in chronically infected bulls resulted in an early increase in specific serum IgM and IgG antibodies, with a higher peak and later decline than those observed after primary infection in the same animals [3]. The specific antibody IgG profile in re-infected bulls was similar to that observed in other re-infected cattle with live $[10,11]$ and inactivated [12] tachyzoites. In bulls with experimentally induced primary infection with $N$. caninum, serum antibody $\operatorname{IgG}$ levels were predominantly close to threshold levels, and sometimes fell to seronegative values. During the chronic stage of neosporosis, lowspecific antibody titres in serum were near the cut-off level of the techniques employed [13,14] and antibody fluctuations [2] that have been reported in naturally infected bulls. The detection of specific antibodies to $N$. caninum in seminal plasma could be an alternative to serology in the diagnosis of bovine neosporosis. However, experiments in naturally infected bulls, especially from AI centres, should be performed to confirm the data from experimentally infected animals. Although the possible toxic effect of specific antibodies on parasite shedding in semen was not investigated, the presence of $N$. caninum DNA associated with the cellular fraction of semen strongly suggests an association between $N$. caninum and phagocytic cells which could act as carriers protecting the protozoa $[2,15]$. It is worth mentioning that the early IFN- $\gamma$ increase highlights the potential use of IFN- $\gamma$ determination as a tool for the diagnosis of a recent $N$. caninum infection in cattle. The lack of correlation between $\operatorname{IgG}$ and IFN- $\gamma$ levels found in our study has also been reported in naturally [2] and experimentally [16] infected cattle, suggesting that factors other than IFN- $\gamma$ regulate $\operatorname{IgG}$ antibody production in cattle.

The most important question derived from the current work and previous studies $[1,15]$ is the possibility of venereal transmission of bovine neosporosis. Despite the low parasite burden found in semen of naturally [2] and experimentally [3] infected bulls and the elevated infectious dose needed to infect heifers by the intrauterine route [4], at present we are involved in field trials that include experimentally infected bulls and seronegative heifers under natural services. The future results will show if venereal transmission plays a role in the spread of bovine neosporosis under natural conditions.

\section{Acknowledgements}

We are grateful to ASEAVA (Asociación de Criadores de Ganado Vacuno Selecto de la Raza Asturiana de los Valles) for providing experimental animals, and especially to José Antonio Cachero and José Luis Antón (SERIDA) and Vanesa Navarro (UCM) for technical assistance. Funding for this work was provided by a research grant from the Spanish government (Pr95-0780.OP) and a research grant from the Complutense University of Madrid (PR3/0412412). Ignacio Ferre was financed by the Ramón y Cajal Spanish Scientific Programme. This work was also part of the EU research collaboration COST-854. This experiment complied with the current laws of animal protection in Spain.

\section{References}

[1] Ortega-Mora LM, Ferre I, del-Pozo I, Caetano-da-Silva A, Collantes-Fernández E, Regidor-Cerrillo J, et al. Detection of Neospora caninum in semen of bulls. Vet Parasitol 2003;117:301-8.

[2] Ferre I, Aduriz G, del-Pozo I, Regidor-Cerrillo J, Atxaerandio R, Collantes-Fernández E, et al. Detection of Neospora caninum in the semen and blood of naturally infected bulls. Theriogenology 2005;63:1504-18.

[3] Serrano-Martínez E, Ferre I, Martínez A, Osoro K, Mateos-Sanz A, del-Pozo I, et al. Experimental neosporosis in bulls: parasite detection in semen and blood and specific antibody and interferon-gamma responses. Theriogenology 2007;67:1175-84.

[4] Serrano-Martínez E, Ferre I, Osoro K, Aduriz G, Mota RA, Martínez A, et al. Intrauterine Neospora caninum inoculation of heifers and cows using contaminated semen with different numbers of tachyzoites. Theriogenology 2007;67:729-37.

[5] Dubey JP, Buxton D, Wouda W. Pathogenesis of bovine neosporosis. J Comp Path 2006;134:267-89.

[6] Collantes-Fernández E, Zaballos A, Álvarez-García G, OrtegaMora LM. Quantitative detection of Neospora caninum in bovine aborted fetuses and experimentally infected mice by real-time PCR. J Clin Microbiol 2002;40:1194-8.

[7] Buxton D, Maley SW, Wright S, Thomson KM, Rae AG, Innes EA. The pathogenesis of experimental neosporosis in pregnant sheep. J Com Pathol 1998;118:267-79.

[8] Staubli D, Iten C, Kneubuhler J, Sager H, Muller N, Gottstein B. Search for Neospora caninum DNA in bull semen using PCR (in German). Schweiz Arch Tierheilkd 2006;148:483-9.

[9] Pituco EM, Okuda LH, Del-Fava C, Stefano E, Shimozono OS, Camargo CN, et al. Pesquisa de Neospora caninum em sêmen de touros de Centrais de Inseminação Artificial do Brasil. In: I Fórum Brasileiro de Estudos sobre Neospora caninum; 2005. pp. 39-41. 
[10] Innes EA, Wright SE, Maley S, Rae A, Schock A, Kirvar E, et al. Protection against vertical transmission in bovine neosporosis. Int J Parasitol 2001;31:1523-34.

[11] Williams DJL, Guy CS, Smith RF, Ellis J, Björkman C, Reichel MP, et al. Immunization of cattle with live tachyzoites of Neospora caninum confers protection against fetal death. Infect Immun 2007;75:1343-8.

[12] Moore DP, Leunda MR, Zamorano PI, Odeón AC, Romera SA, Cano A, et al. Immune response to Neospora caninum in naturally infected heifers vaccinated with inactivated antigen during the second trimester of gestation. Vet Parasitol 2005;130:29-39.

[13] Moore DP, Draghi MG, Campero CM, Cetrá B, Odeón AC, Alcaraz E, et al. Serological evidence of Neospora caninum infections in beef bulls in six counties of the Corrientes province, Argentina. Vet Parasitol 2003;114:247-52.

[14] Caetano-da-Silva A, Ferre I, Aduriz G, Álvarez-García G, delPozo I, Atxaerandio R, et al. Neospora caninum infection in breeder bulls: seroprevalence and comparison of serological methods used for diagnosis. Vet Parasitol 2004;124:19-24.

[15] Caetano-da-Silva A, Ferre I, Collantes-Fernández E, Navarro V, Aduriz G, Ugarte-Garagalza C, et al. Occasional detection of Neospora caninum DNA in frozen extended semen from naturally infected bulls. Theriogenology 2004;62:1329-36.

[16] Andrianarivo AG, Barr BC, Anderson ML, Rowe JD, Packham $\mathrm{AE}$, Sverlow $\mathrm{KW}$, et al. Immune responses in pregnant cattle and bovine fetuses following experimental infection with Neospora caninum. Parasitol Res 2001;87:817-25. 